\title{
Dasatinib reverses drug resistance by downregulating MDR1 and Survivin in Burkitt lymphoma cells
}

\author{
Mitsuki Tabata', Masanobu Tsubaki', Tomoya Takeda', Keisuke Tateishi', Katsumasa Tsurushima 1,2, \\ Motohiro Imano ${ }^{3}$, Takao Satou ${ }^{4}$, Toshihiko Ishizaka ${ }^{2}$ and Shozo Nishida ${ }^{1^{*}}$ (D)
}

\begin{abstract}
Background: Current chemotherapies for Burkitt lymphoma (BL) have dramatically improved its clinical outcome. However, chemoresistance can lead to chemotherapy failure and very poor prognosis; thus, novel strategies are urgently required for patients with drug-resistant $\mathrm{BL}$. To investigate the mechanisms underlying drug resistance in BL, we established drug-resistant BL cell lines: HS-Sultan/ADM (adriamycin-resistant), HS-Sultan/NCR (vincristineresistant), HS-Sultan/DEX (dexamethasone-resistant), and HS-Sultan/L-PAM (melphalan-resistant).

Methods: Drug transporter and survival factor expression were investigated the using western blotting and real time polymerase chain reaction. Cell survival was analyzed by trypan blue dye exclusion method.

Results: The established cell lines acquired cross-resistance to adriamycin, vincristine, dexamethasone, and melphalan and exhibited 50\% inhibitory concentration values 106-, 40-, 81-, and 45-fold higher than the parental cell lines, respectively. We found that protein and mRNA expression of MDR1 and Survivin were higher in drug-resistant BL cells than in the parent cells. Treatment with verapamil, an MDR1 inhibitor, or Survivin siRNA alongside each anti-cancer drug suppressed the proliferation of all drug-resistant BL cells. Src kinase activity was higher in all resistant cell lines than the parental cells; suppressing Src with dasatinib restored drug sensitivity by reducing MDR1 and Survivin expression.

Conclusions: MDR1 and Survivin upregulation are responsible for resistance to conventional drugs and dasatinib can restore drug sensitivity by reducing MDR1 and Survivin expression in drug-resistant BL cells. Src inhibitors could therefore be a novel treatment strategy for patients with drug resistant BL.
\end{abstract}

Keywords: Drug resistance, MDR1, Survivin, Src, Dasatinib

\section{Background}

Burkitt lymphoma (BL) is a fast-growing B-cell malignancy that accounts for $1-5 \%$ of acute lymphoblastic leukemias and non-Hodgkin lymphomas (NHL) [1]. Since BL is relatively sensitive to chemotherapy, the current high-dose/intensive chemotherapy and rituximab treatment achieves a three-year overall survival

\footnotetext{
*Correspondence: nishida@phar.kindai.ac.jp

'Division of Pharmacotherapy, Kindai University Faculty of Pharmacy, Kowakae, Higashi-Osaka 577-8502, Japan

Full list of author information is available at the end of the article
}

rate of over $80 \%$ [2-5]. However, chemoresistance can result in chemotherapy failure [6]. Patients with relapsed/refractory BL show a median overall survival of just 2.8 months [7]; thus, novel strategies are urgently required for patients with drug-resistant BL. ATP-binding cassette transporters, including multiple drug resistance 1 (MDR1, $\mathrm{ABCB} 1$ ), multidrug resistance-associated protein 1 (MRP1, $A B C C 1)$, and breast cancer resistance protein (BCRP, ABCG2) translocate drugs across the plasma membrane. The lung resistance protein 1 (LRP1) transports drugs

(c) The Author(s). 2020 Open Access This article is licensed under a Creative Commons Attribution 4.0 International License, which permits use, sharing, adaptation, distribution and reproduction in any medium or format, as long as you give appropriate credit to the original author(s) and the source, provide a link to the Creative Commons licence, and indicate if changes were made. The images or other third party material in this article are included in the article's Creative Commons licence, unless indicated otherwise in a credit line to the material. If material is not included in the article's Creative Commons licence and your intended use is not permitted by statutory regulation or exceeds the permitted use, you will need to obtain permission directly from the copyright holder. To view a copy of this licence, visit http://creativecommons.org/licenses/by/4.0/ The Creative Commons Public Domain Dedication waiver (http://creativecommons.org/publicdomain/zero/1.0/) applies to the data made available in this article, unless otherwise stated in a credit line to the data. 
away from their target molecules via cytoplasmic vesicles or pump molecules. The upregulation of these molecules has leads to cause drug resistance by reducing intracellular anti-cancer drug accumulation [812], thus is regarded as a marker of poor prognosis [13-18]. Apoptosis evasion, a hallmark of cancer, is responsible for both carcinogenesis and chemoresistance in various tumors. Bcl-2 and Bcl-XL, a member of anti-apoptotic Bcl-2 family proteins, suppress apoptosis by involving mitochondrial outer membrane permeability [19], yet inhibitor of apoptosis (IAP) family proteins do so by inhibiting caspase activity $[20,21]$. Most anti-cancer drugs suppress tumor proliferation by inducing apoptosis, hence the overexpression of anti-apoptotic proteins results in drug resistance [2225]. To understand drug resistance, further studies are required on the underlying intracellular signaling pathways.

Src kinase is a non-receptor tyrosine kinase which was involved in gene expression, immune responses, cell adhesion, cell cycle progression, apoptosis, migration, and transformation. Since it is responsible for tumor growth, metastasis, and angiogenesis, Src has been targeted for cancer treatment [26, 27]. In addition, Src is overactivated in various B lymphoma cell lines and patient-derived lymphoma, and inhibition of Src by PP1 and PP2 suppresses cell proliferation and induces cell death in BL cell line BAJB [28-30]. It has also been indicated that activation of Fyn and Syk by latent membrane protein 1 induces the Src/Akt pathway, which promotes cell proliferation and survival in Epstein-Barr virus-positive BL cells [31]. Our previous study showed that activation of Src induces multidrug resistance to anticancer drugs in multiple myeloma cells [32]. However, it is unclear whether activation of $\mathrm{Src}$ is involved with anticancer drug resistance in BL. Dasatinib is a therapeutic agent for chronic myeloid leukemia and a dual inhibitor of BCR/ABL and Src family kinases [33]. Src inhibition by dasatinib has been reported to resensitize drug-resistant cells to anti-cancer drugs [32, 34-36]; however, the effect of dasatinib in drugresistant BL has not yet been investigated.

This study investigated the mechanisms of anticancer drug resistance and established therapeutic strategies for patients with drug-resistant BL.

\section{Methods}

\section{Chemicals and reagents}

Melphalan, adriamycin, vincristine, RPMI1640 medium, pepstatin, leupeptin, calpain inhibitor, phosphatase inhibitor cocktail I/II, and phenylmethylsulfonyl fluoride were purchased from Sigma (St. Louis, MO, USA). Dexamethasone, verapamil, 4-(2-hydroxyethyl)-1-piperazineethanesulfonic acid (HEPES), Tris- $\mathrm{HCl}$ (pH 7.4), EDTA, NP-40, sodium orthovanadate, and bicinchoninic acid protein-assay kit were purchased from Wako (Tokyo, Japan). Dasatinib was purchased from ChemieTek (Indianapolis, USA). Fetal bovine serum, penicillin, and streptomycin were purchased from Gibco (Carlsbad, CA, USA).

Melphalan, dexamethasone, and dasatinib were soluble in dimethyl sulfoxide, attenuated in phosphatebuffed saline (PBS); pH 7.4, and filtrated through $0.45 \mu \mathrm{m}$ syringe (Iwaki Glass, Tokyo, Japan) filter before use. Adriamycin and vincristine were soluble in PBS. Verapamil was soluble in ultrapure water, and filtrated through $0.45 \mu \mathrm{m}$ syringe (Iwaki Glass) filter before use.

\section{Cell culture}

The human Burkitt lymphoma cell line HS-Sultan was provided from the DS Pharma Biomedical (EC87012701, Osaka, Japan). These cells were cultured in RPMI1640 medium (Sigma) including $100 \mu \mathrm{g} / \mathrm{mL}$ penicillin (Gibco), $10 \%$ fetal bovine serum (Gibco), $100 \mathrm{U} / \mathrm{mL}$ streptomycin (Gibco), and $25 \mathrm{mM} \mathrm{HEPES} \mathrm{(pH} \mathrm{7.4;} \mathrm{Wako).}$

\section{Induction of anti-cancer drug resistance}

HS-Sultan cells with acquired resistance to adriamycin, vincristine, dexamethasone, or melphalan were produced as previously described [12, 37, 38].

\section{Cell proliferation and survival assay}

The effect of verapamil, adriamycin, vincristine, dexamethasone, melphalan, dasatinib, or Survivin siRNA on cell survival and proliferation was assessed using the trypan blue dye exclusion assay as previously described [12].

\section{Western blotting}

Cytoplasmic cell fraction was collected by using cell lysis buffer (20 mM Tris- $\mathrm{HCl}$ (pH 8.0; Wako), $2 \mathrm{mM}$ EDTA (Wako), 0.5\% NP-40 (Wako), $1 \mu \mathrm{M}$ pepstatin (Sigma), $1 \mu \mathrm{M}$ leupeptin (Sigma), $2 \mathrm{mM}$ sodium orthovanadate (Wako), $1 \mu \mathrm{M}$ calpain inhibitor (Sigma), phosphatase inhibitor cocktail I/II (Sigma), and $1 \mathrm{mM}$ phenylmethylsulfonyl fluoride (Sigma)). The protein contained amount of these fraction was evaluated using a bicinchoninic acid protein-assay kit (Wako). The extracts $(40 \mu \mathrm{g}$ of protein) were separated on sodium dodecyl sulfate polyacrylamide gels and transferred to polyvinyl difluoride membranes (GE Healthcare, Buckinghamshire, UK). The membranes were reacted with the following antibodies: anti-Bcl-2, anti-Bcl-xL, anti-Survivin, anti-MDR1, anti-BCRP, anti-MRP1, antiLRP1 (Santa Cruz Biotechnologies, CA, USA), antiphospho-Src (Tyr527), anti-Src (Cell Signaling Technology, Beverly, MA), and anti- $\beta$-actin (Sigma) as an internal 
control. The membranes were reacted with horseradish peroxidase-coupled secondary antibodies (GE Healthcare) for $1 \mathrm{~h}$ at room temperature and proteins were assessed using a Luminata Forte (Merck Millipore, Nottingham, UK).

\section{Quantitative real-time polymerase chain reaction (PCR)}

The expression of MDR1 and Survivin mRNA was assessed using a Thermal Cycler Dice Real-Time system (Takara Biomedical) as previously described [12].

\section{RNA interference}

Transfection of Survivin siRNA (siRNAs; HSS179403) were performed using LipofectAMINE ${ }^{\mathrm{m}} 2000$ reagent (Invitrogen) according to the manufacturer's protocol as previously described [12].

\section{Statistical analysis}

All data are demonstrated as the mean \pm standard deviation of five independent experiments. All analysis were carried out by ANOVA with Dunnett's test. $P$ values of $<0.05$ were regarded significant. Drug interactions were measured based on the combination index $(\mathrm{CI})$, as previously described [24, 39].

\section{Results}

Drug sensitivity of established adriamycin-, vincristine-, dexamethasone-, and melphalan-resistant BL cell lines We found that our established resistant cell lines, HSSultan/ADM (adriamycin-resistant), HS-Sultan/VCR (vincristine-resistant), HS-Sultan/DEX (dexamethasone-resistant), and HS-Sultan/L-PAM (melphalan-resistant), showed similar proliferation to the parental HS-Sultan cells; administration with adriamycin, vincristine, dexamethasone, and melphalan did not induced cell death in HS-Sultan/ADM, HS-Sultan/VCR, HS-Sultan/DEX, and HS-Sultan/L-PAM cells, but induced cell death in HS-Sultan cells (Fig. 1a). The IC50 values of the HS-Sultan cells for adriamycin, vincristine, dexamethasone, and melphalan were $0.221,0.0073$, 3.777 , and $1.424 \mu \mathrm{M}$, respectively. In contrast, the IC50 values of HS-Sultan/ADM, HS-Sultan/VCR, HS-Sultan/ DEX, and HS-Sultan/L-PAM cells for adriamycin, vincristine, dexamethasone, and melphalan were 23.471, $0.290,304.919$, and $64.558 \mu \mathrm{M}$, respectively, 106-, 40-, 81 -, and 45-fold higher than those of the HS-Sultan cells (Fig. 1b). Furthermore, all resistant cell lines acquired cross-resistance to adriamycin, vincristine, dexamethasone, and melphalan (Fig. 1c).

\section{MDR1 and Survivin expression levels increased in drug- resistant BL cell lines}

We investigated the expression levels of a series of efflux pumps and apoptosis-related proteins in HS-Sultan, HSSultan/ADM, HS-Sultan/VCR, HS-Sultan/DEX, and HS-
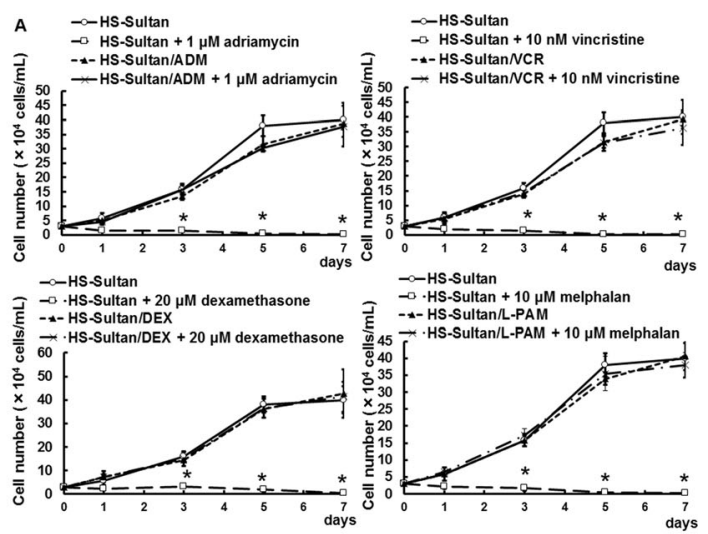

B $\quad-$-HS-Sultan $\rightarrow$-HS-Sultan/ADM
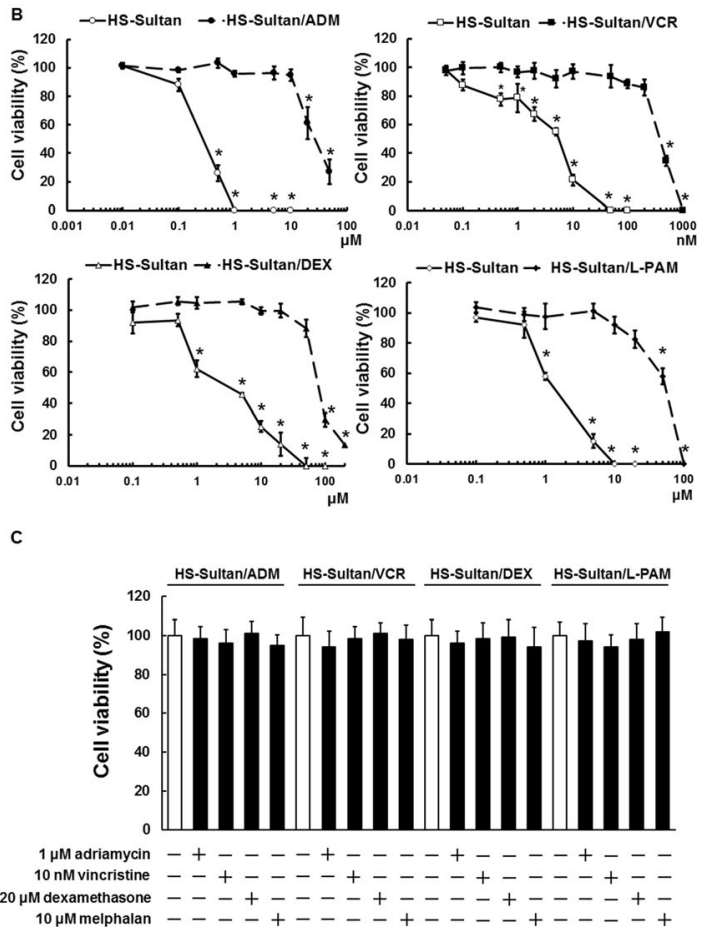

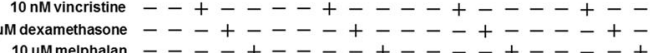

Fig. 1 HS-Sultan/ADM, HS-Sultan NCR, HS-Sultan /DEX, and HSSultan /L-PAM cell production and viability with various drugs. a HSSultan, HS-Sultan/ADM, HS-Sultan/VCR, HS-Sultan/DEX, and HSSultan/L-PAM cells were cultured with the represented concentrations of adriamycin, vincristine, dexamethasone, and melphalan. Cell number was appreciated using a trypan blue dye exclusion assay after 1, 3, 5, or 7 days. Results are notable example of five independent experiments. ${ }^{*} p<0.01$ vs. untreated HS-Sultan cells (ANOVA with Dunnett's test). b HS-Sultan, HS-Sultan/ADM, HSSultan/NCR, HS-Sultan/DEX, and HS-Sultan/L-PAM cells were cultured with the represented concentrations of adriamycin, vincristine, dexamethasone, and melphalan for $72 \mathrm{~h}$. Cell viability was appreciated using a trypan blue dye exclusion assay. Results are notable example of five independent experiments. ${ }^{*} p<0.01$ vs. control (ANOVA with Dunnett's test). c Cross-resistance of drugresistant BL cell lines. HS-Sultan/ADM, HS-Sultan/NCR, HS-Sultan/DEX, and HS-Sultan/L-PAM cells were cultured with $1 \mu \mathrm{M}$ adriamycin, 10 $\mathrm{nM}$ vincristine, $20 \mu \mathrm{M}$ dexamethasone, or $10 \mu \mathrm{M}$ melphalan for $72 \mathrm{~h}$. Cell number was detected using a trypan blue dye exclusion assay 
Sultan/L-PAM cells. Expression of MDR1 and Survivin protein levels were substantially elevated in all resistant cells than the parental cells; however, Bcl-2, Bcl-xL, MRP1, LRP1, and BCRP expression did not change (Fig. 2a, b). Expression of MDR1 and Survivin mRNA levels were also elevated in all resistant cell lines than in the parental cells (Fig. 2c), suggesting that overexpressed expression of MDR1 and Survivin play an significant role in acquired drug resistance.

\section{Verapamil or Survivin siRNA treatment reversed adriamycin, vincristine, dexamethasone, and melphalan resistance}

To determine whether MDR1 and Survivin were involved in acquired drug resistance, we assessed the viability of HSSultan/ADM, HS-Sultan/VCR, HS-Sultan/DEX, and HSSultan/L-PAM cells treated with verapamil, an MDR1 inhibitor, or Survivin siRNA. As shown in Fig. 3a, the combined treatment of verapamil with adriamycin, vincristine, dexamethasone, or melphalan induced cell death in all resistant cells. Verapamil treatment alone did not affect the viability of either the drug-sensitive or drug-resistant cells.
The Survivin siRNA treatment $(20 \mathrm{nM})$ was sufficient to suppress Survivin expression (Fig. 3b) and the viability of all resistant cell lines when combined with each anti-cancer agent (Fig. 3c). These results suggest that targeting MDR1 and Survivin could overcome drug resistance.

\section{Dasatinib overcame drug resistance by downregulating MDR1 and Survivin}

We investigated whether Src affected drug resistance in HSSultan/ADM, HS-Sultan/VCR, HS-Sultan/DEX, and HSSultan/L-PAM cells. Src phosphorylation levels were higher in all resistant BL cells than in HS-Sultan cells (Fig. 4a, b) and dasatinib restored drug sensitivity in all resistant cells at the indicated concentration (Fig. 4c). In addition, the interactions among dasatinib and adriamycin, vincristine, dexamethasone, or melphalan were analyzed using the ChouTalalay method. Per the combination drug concentrations shown in Fig. 4d, the CI ranged from 0.824 to 0.049 , indicating the synergistic effect of these combinations (Fig. 4d). Next, we investigated MDR1 and Survivin expression levels in resistant cells treated with dasatinib. Dasatinib treatment reduced MDR1 and Survivin expression levels to the same
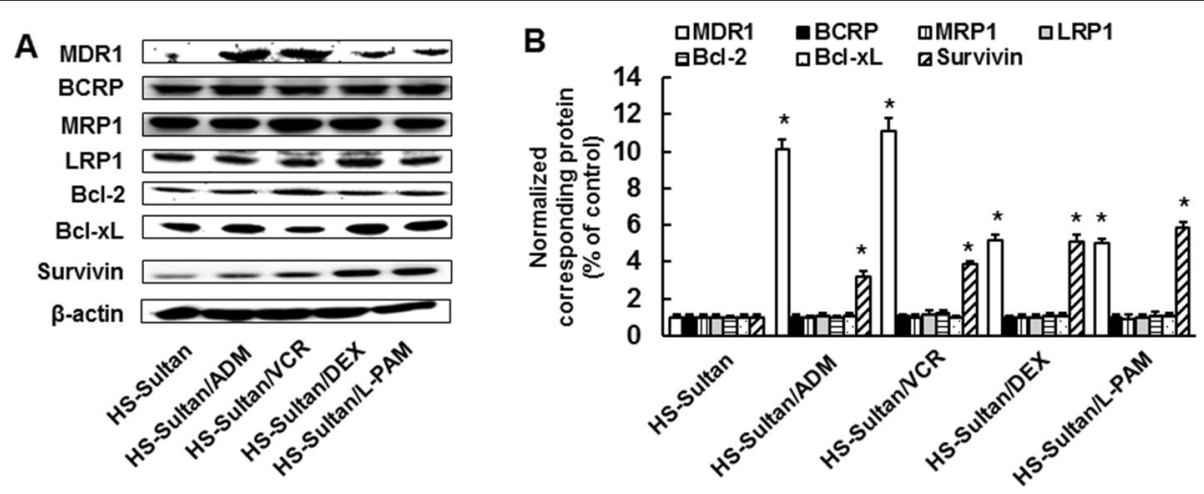

C

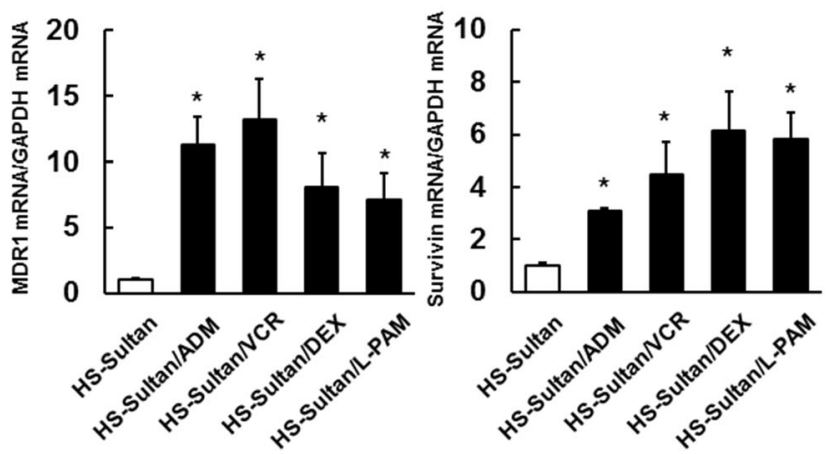

Fig. 2 Expression levels of drug resistance-related proteins in HS-Sultan/ADM, HS-Sultan/VCR, HS-Sultan/DEX, and HS-Sultan/L-PAM cells. a Expression levels of a series of efflux pumps and anti-apoptosis proteins were assessed by western blotting analysis. Cytoplasmic cell fractions were extracted and performed to SDS-PAGE/immunoblotting with anti-MDR1, anti-BCRP, anti-MRP1, anti-LRP1, anti-BCl-2, anti-BCl-XL, and antiSurvivin antibodies. Anti- $\beta$-actin antibodies were used as an internal control. b Quantification of MDR1, BCRP, MRP1, LRP1, BCl-2, BCL-xL, or Survivin levels, normalized to the amount of the $\beta$-actin. Results are notable example of five independent experiments. ${ }^{*} p<0.01$ vs. control cells (ANOVA with Dunnett's test). c mRNA expression of MDR1 and Survivin analyzed by real-time PCR. The results were normalized to GAPDH mRNA levels. Results are notable example of five independent experiments. ${ }^{*} p<0.01 \mathrm{vs}$. control (ANOVA with Dunnett's test) 
A

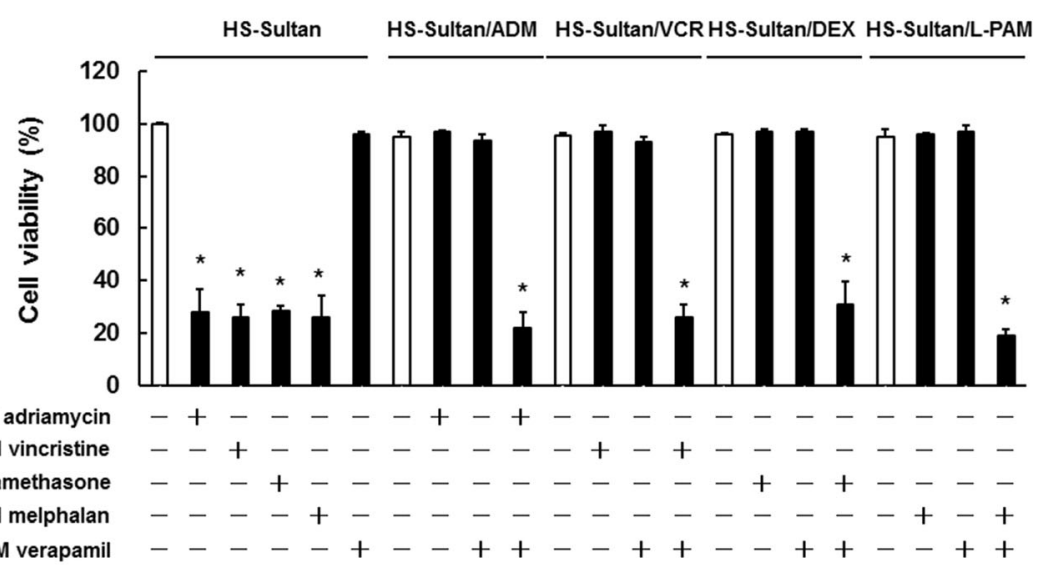

B

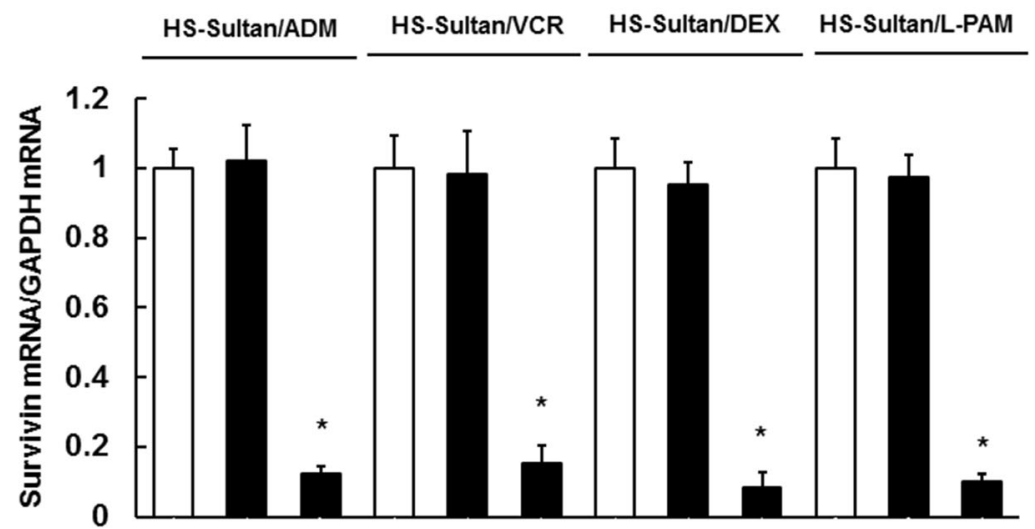

20 nM negative siRNA -+--+--+--+

20 nM SurvivinsiRNA $--+--+-\infty+-+$

C

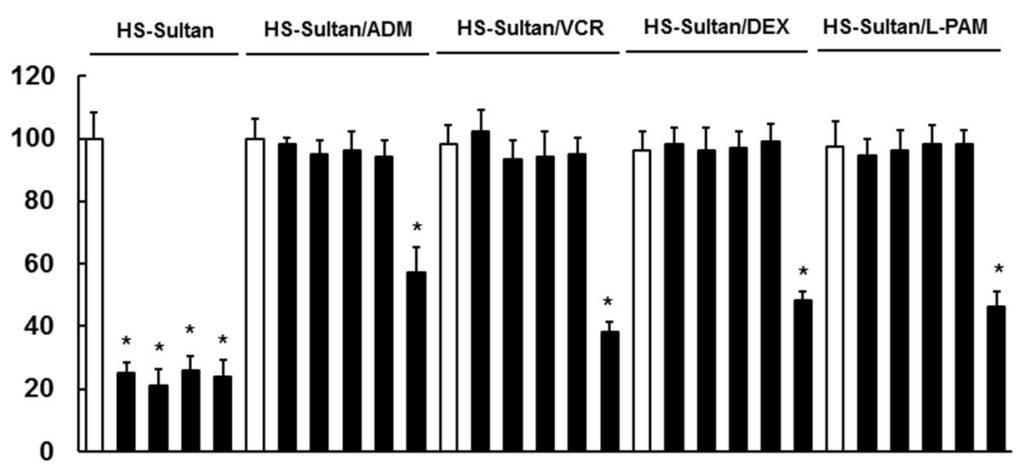

$1 \mu \mathrm{M}$ adriamycin

$10 \mathrm{nM}$ vincristine

$20 \mu \mathrm{M}$ dexamethasone

$10 \mu \mathrm{M}$ melphalan

$20 \mathrm{nM}$ negative siRNA

$20 \mathrm{nM}$ Survivin siRNA

$-+-----+++------------$

$--+--------+++--------$

$---+------------+++-----$

$---+-------------+++$

$-----+--+--+--+--+--+--+--+-$

$------+--+--+--+--+--+--+--+$

Fig. 3 (See legend on next page.) 


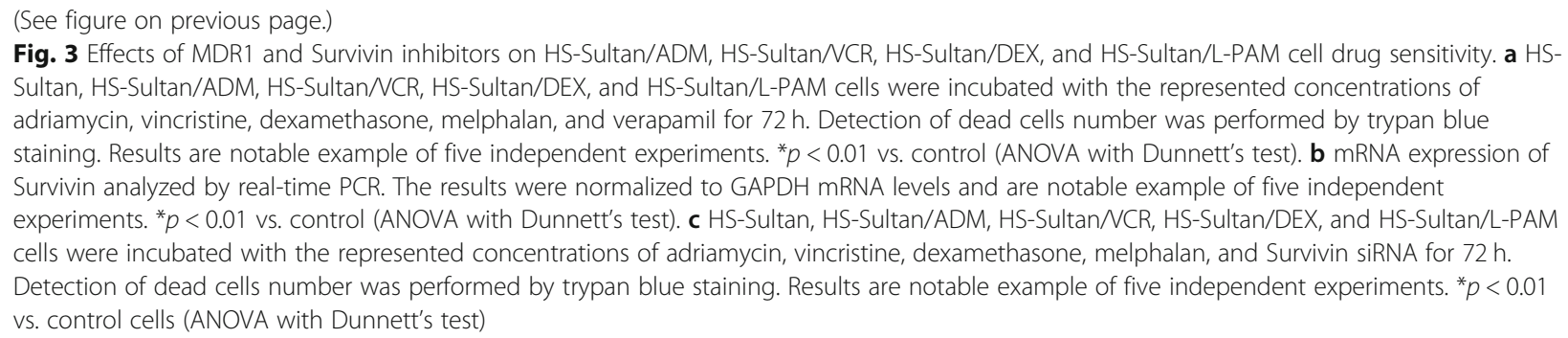

extent in all resistant cells compared to the parental HSSultan cells (Fig. 4e, f), indicating that Src inhibition could restore drug sensitivity by reducing overexpression of MDR1 and Survivin in acquired drug-resistant BL cells.

\section{Discussion}

To investigate the mechanisms of anti-cancer drug resistance, we established drug-resistant BL cell lines, including HS-Sultan/ADM, HS-Sultan/VCR, HS-Sultan/ DEX, and HS-Sultan/L-PAM cells. The resistant cells showed similar growth to parental HS-Sultan cells and displayed higher IC50 values than the parental cells for adriamycin, vincristine, dexamethasone, and melphalan, respectively. In addition, all resistant cells acquired cross-resistance to other anti-cancer drugs.

In this study, MDR1 and Survivin protein and mRNA expression levels were elevated in all resistant cells than in the parental cells. Moreover, verapamil and Survivin siRNA reversed adriamycin, vincristine, dexamethasone, and melphalan resistance. It has been reported that MDR1 overexpression in Namalwa cells, a human BL cell line, promotes the efflux of adriamycin and vincristine and induces drug resistance [40]. It has also been indicated that inhibition of MDR1/P-glycoprotein function by verapamil re-sensitizes the cytotoxic effect of vincristine in vincristine-resistant Namalwa and Raji cells [41]. In addition, MDR1/P-glycoprotein overexpression induces resistance to treatment with the CHOP (cyclophosphamide, adriamycin, vincristine, prednisolone) regimen in patients with NHL including BL [42]. The expression of Survivin, a member of the IAP protein family that inhibits caspase activity, is higher in patients with BL than in patients with reactive lymphoid hyperplasia [43]. In addition, high expression of Survivin in patients with BL was associated with resistance to chemotherapy compared to low expression of Survivin in patients with BL [44]. It has been reported that YM155, a Survivin inhibitor, suppresses tumor growth and prolongs the survival time in SCID mice bearing the Ramos BL cell line compared to rituximab [45]. These findings suggest that MDR1 and Survivin are correlated with drug resistance, and inhibition of these factors re-sensitize the anticancer drugs.
Src kinase is responsible for tumor survival, hence this molecule has been reported as an attractive target for cancer treatment $[26,27,46]$. Dasatinib, an Src inhibitor, has been reported to resensitize drug-resistant cells to anti-cancer drugs [32, 34-36, 47]. In this study, Src activity was elevated in all resistant cells than in the parental cells, while dasatinib, an Src inhibitor, reversed adriamycin, vincristine, dexamethasone, and melphalan resistance. In addition, dasatinib reduced Src phosphorylation and MDR1 and Survivin protein expression in resistant cells to less than or equal to that of the parental cells. It has been indicated that dasatinib suppresses diffuse large B-cell lymphoma cell proliferation in vitro and tumor growth in vivo through inhibition of Src phosphorylation [29]. In addition, Src activation by gap junction beta-4-induced chemoresistance to gemcitabine and etoposide, in addition to dasatinib enhances the cytotoxic effect of gemcitabine in lung cancer [48]. It has been reported that dasatinib enhances the inhibitory effect of tumor cell growth by trametinib, a mitogenactivated protein kinase kinase inhibitor, in vitro and in vivo in various KRAS-mutant cancer cells, including lung, breast, colon, and pancreatic cancer cells [49]. Dasatinib has also been shown to increase cisplatin sensitivity in esophageal squamous cell carcinoma and adriamycin sensitivity in breast cancer by downregulating MDR1 [50, 51]. Moreover, dasatinib has been shown to reduce MDR1 and Survivin levels; increase Bim levels; and restore adriamycin, vincristine, dexamethasone, and melphalan sensitivity in drug-resistant multiple myeloma cells [32]. Our results clearly show the first evidence of an anticancer drug-resistant mechanism through the activation of Src in BL cells. In addition, dasatinib overcomes anticancer drug resistance via inhibition of Src phosphorylation and MDR1 and Survivin expression in BL cells and similarly drug-resistant multiple myeloma cells. Collectively, these findings suggest that dasatinib is re-sensitized to anticancer drugs in drug-resistant BL.

\section{Conclusions}

In conclusion, we found that MDR1 and Survivin upregulation is responsible for resistance to conventional drugs. 
A

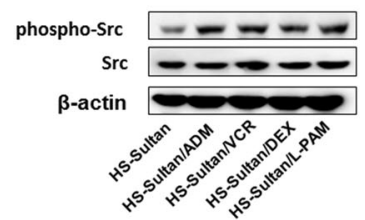

c

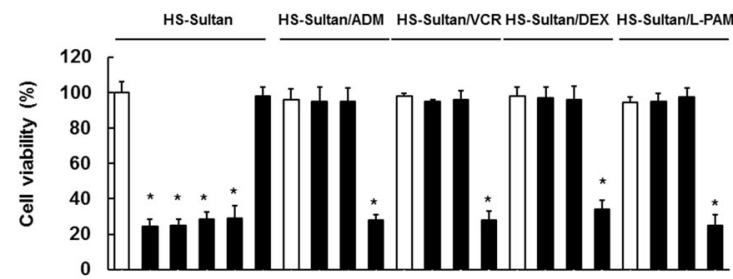

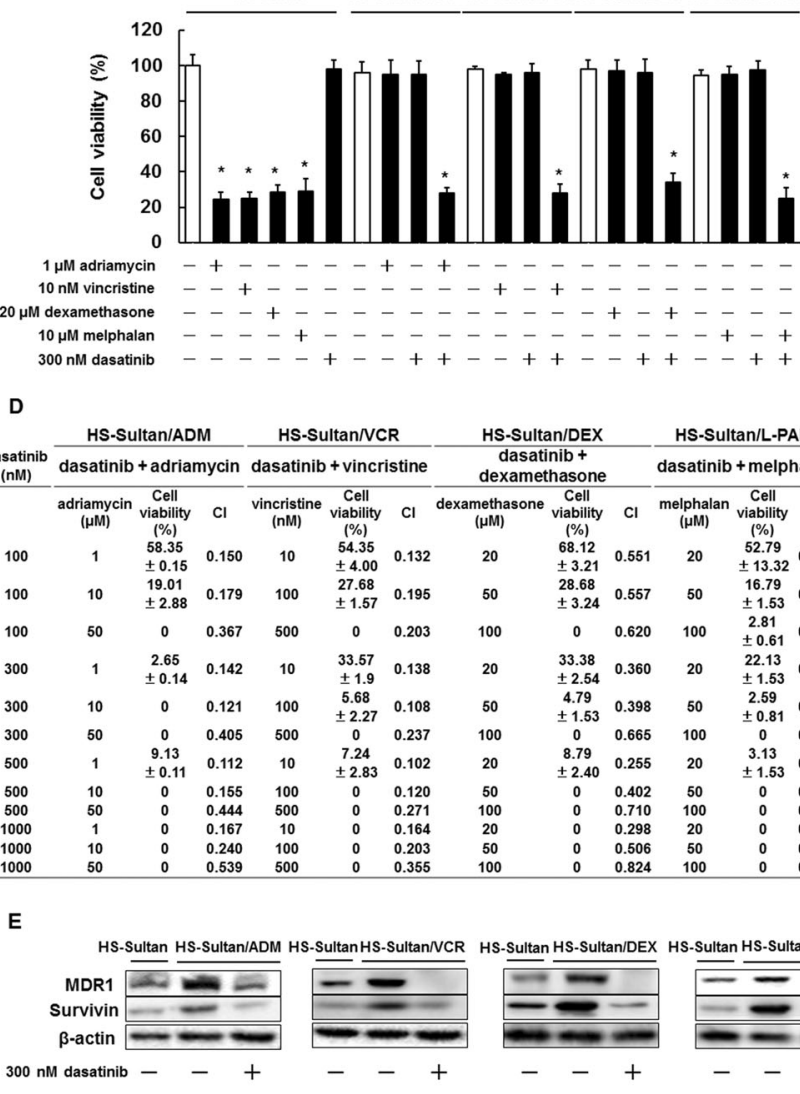

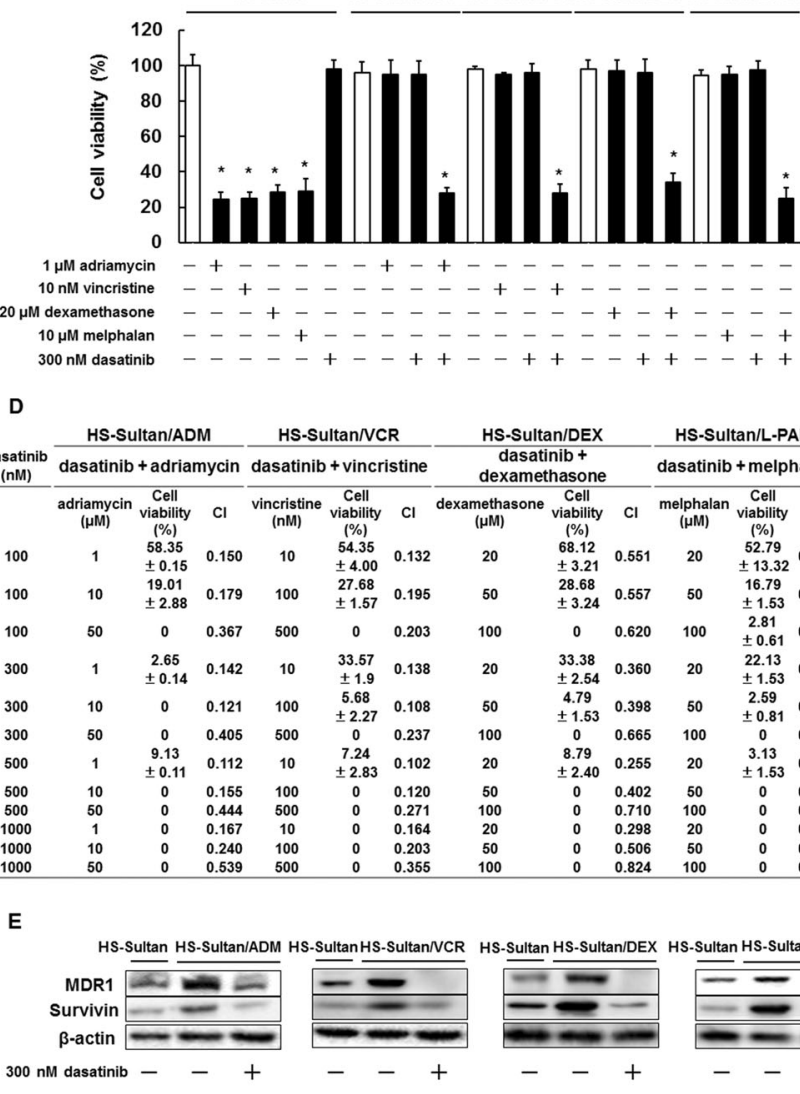

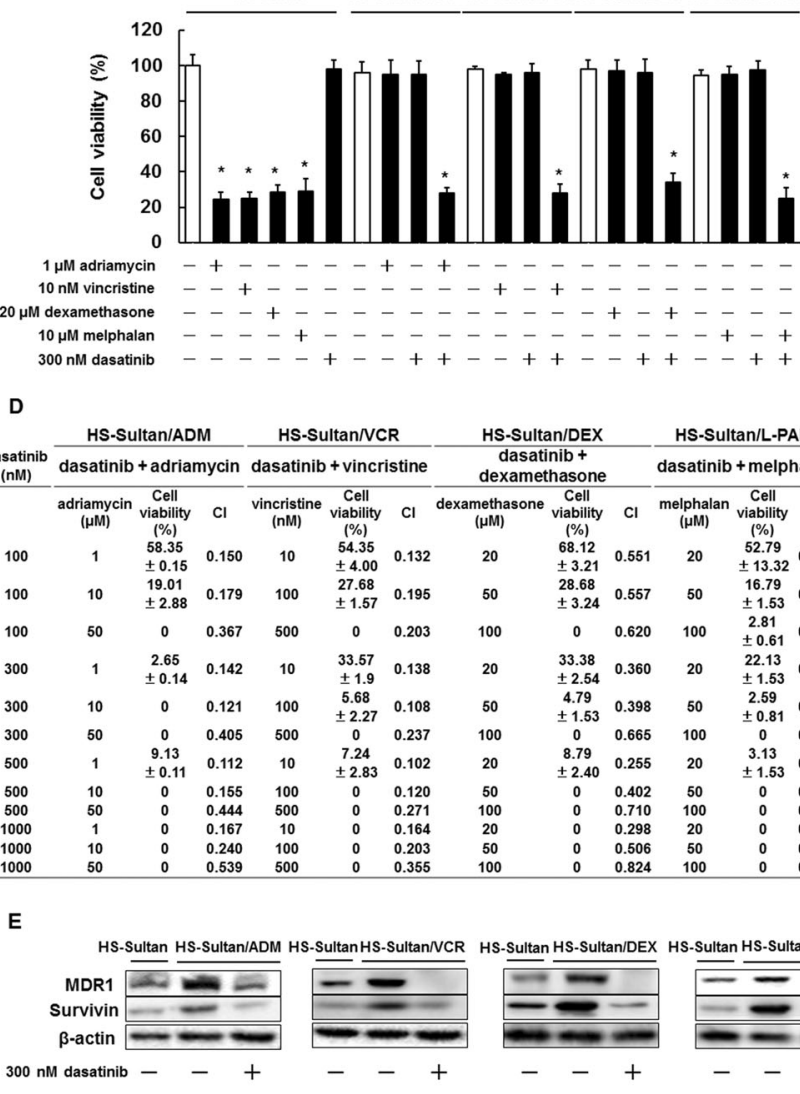

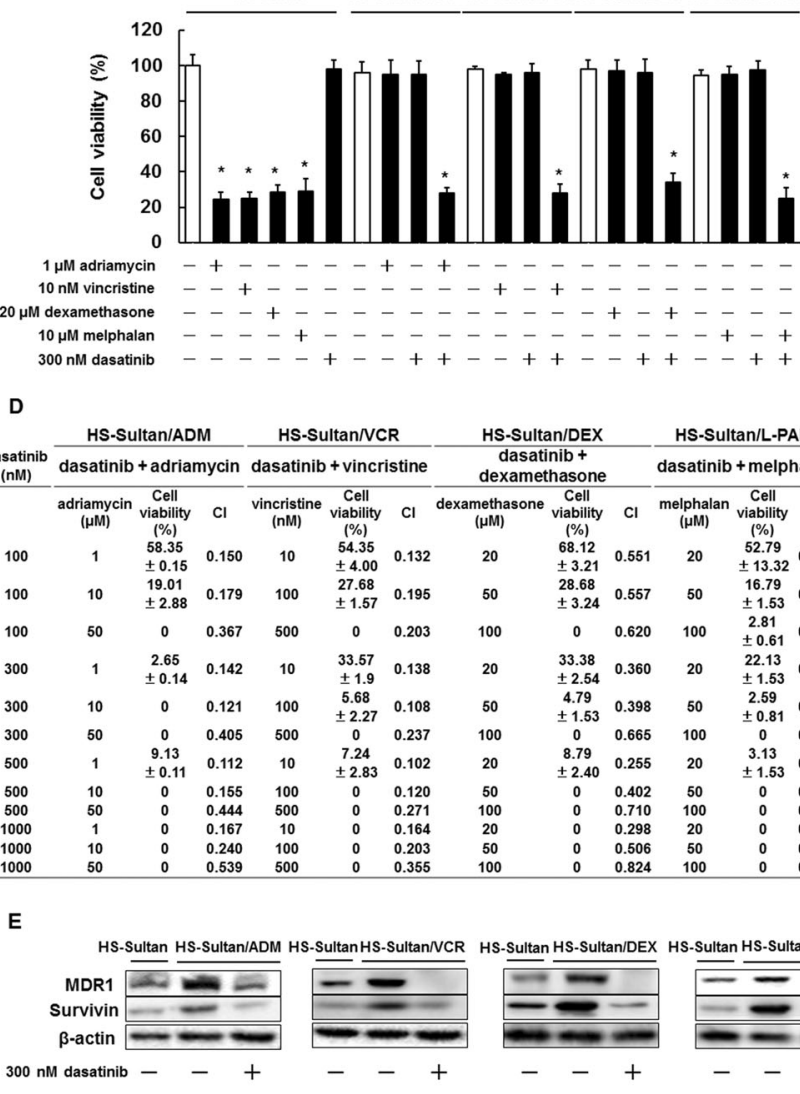

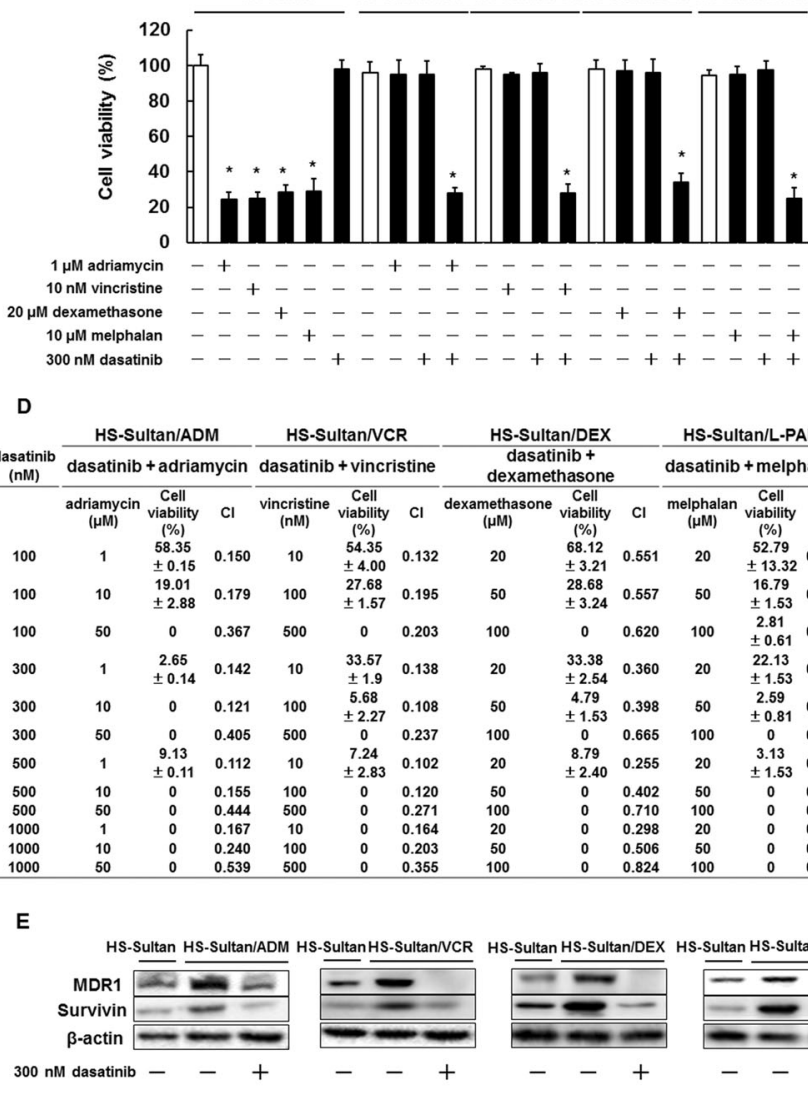

\begin{tabular}{|c|c|c|c|c|c|c|c|c|c|c|c|c|}
\hline \multirow{3}{*}{$\begin{array}{c}\text { dasatinib } \\
\text { (nM) }\end{array}$} & \multicolumn{3}{|c|}{ HS-Sultan/ADM } & \multirow{2}{*}{\multicolumn{3}{|c|}{ HS-Sultan/VCR }} & \multirow{2}{*}{\multicolumn{3}{|c|}{$\begin{array}{c}\text { HS-Sultan/DEX } \\
\text { dasatinib }+ \\
\text { dexamethasone }\end{array}$}} & \multirow{2}{*}{\multicolumn{3}{|c|}{$\frac{\text { HS-Sultan/L-PAM }}{\text { dasatinib + melphalan }}$}} \\
\hline & dasatinib & + adria & nycin & & & & & & & & & \\
\hline & $\begin{array}{c}\text { adriamycin } \\
(\mu \mathrm{M})\end{array}$ & $\begin{array}{l}\text { Cell } \\
\text { viability } \\
(\%)\end{array}$ & $\mathrm{Cl}$ & $\begin{array}{c}\text { vincristine } \\
\text { (nM) }\end{array}$ & $\begin{array}{l}\text { Cell } \\
\text { viability } \\
(\%)\end{array}$ & $\mathrm{Cl}$ & $\begin{array}{c}\text { dexamethasone } \\
(\mu M)\end{array}$ & $\begin{array}{l}\text { Cell } \\
\text { viability } \\
(\%)\end{array}$ & $\mathrm{Cl}$ & $\underset{(\mu \mathrm{M})}{\text { melphalan }}$ & $\begin{array}{l}\text { Cell } \\
\text { viability } \\
(\%)\end{array}$ & $\mathrm{Cl}$ \\
\hline 100 & 1 & $\begin{array}{l}58.35 \\
\pm 0.15\end{array}$ & 0.150 & 10 & $\begin{array}{l}54.35 \\
\pm 4.00\end{array}$ & 0.132 & 20 & $\begin{array}{l}68.12 \\
\pm 3.21\end{array}$ & 0.551 & 20 & $\begin{array}{c}52.79 \\
\pm 13.32\end{array}$ & 0.145 \\
\hline 100 & 10 & $\begin{array}{l}19.01 \\
\pm 2.88\end{array}$ & 0.179 & 100 & $\begin{array}{l}27.68 \\
\pm 1.57\end{array}$ & 0.195 & 50 & $\begin{array}{l}28.68 \\
\pm 3.24\end{array}$ & 0.557 & 50 & $\begin{array}{l}16.79 \\
\pm 1.53\end{array}$ & 0.048 \\
\hline 100 & 50 & 0 & 0.367 & 500 & 0 & 0.203 & 100 & 0 & 0.620 & 100 & $\begin{array}{c}2.81 \\
\pm 0.61\end{array}$ & 0.073 \\
\hline 300 & 1 & $\begin{array}{c}2.65 \\
\pm 0.14\end{array}$ & 0.142 & 10 & $\begin{array}{l}33.57 \\
\pm 1.9\end{array}$ & 0.138 & 20 & $\begin{array}{l}33.38 \\
\pm 2.54\end{array}$ & 0.360 & 20 & $\begin{array}{l}22.13 \\
\pm 1.53\end{array}$ & 0.102 \\
\hline 300 & 10 & 0 & 0.121 & 100 & $\begin{array}{c}5.68 \\
\pm 2.27\end{array}$ & 0.108 & 50 & $\begin{array}{c}4.79 \\
+1.53\end{array}$ & 0.398 & 50 & $\begin{array}{c}2.59 \\
\pm 0.81\end{array}$ & 0.063 \\
\hline 300 & 50 & 0 & 0.405 & 500 & 0 & 0.237 & 100 & 0 & 0.665 & 100 & 0 & 0.093 \\
\hline 500 & 1 & $\begin{array}{r}9.13 \\
+0.11\end{array}$ & 0.112 & 10 & $\begin{array}{c}7.24 \\
+2.83\end{array}$ & 0.102 & 20 & $\begin{array}{c}8.79 \\
+8.40\end{array}$ & 0.255 & 20 & $\begin{array}{c}3.13 \\
+153\end{array}$ & 0.093 \\
\hline 50 & & 0 & & & 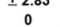 & & & $\begin{array}{ll} \pm 2.40 \\
0\end{array}$ & 0.402 & & 0 & 0.090 \\
\hline & 50 & 0 & & & 0 & & & 0 & & & 0 & \\
\hline & 1 & 0 & & & 0 & & & 0 & 0.29 & 20 & 0 & 0.165 \\
\hline & & 0 & & & 0 & & & 0 & 506 & & 0 & 0.171 \\
\hline 1000 & 50 & 0 & 0.539 & 500 & 0 & 0.355 & 100 & 0 & 0.824 & 100 & 0 & 0.198 \\
\hline
\end{tabular}

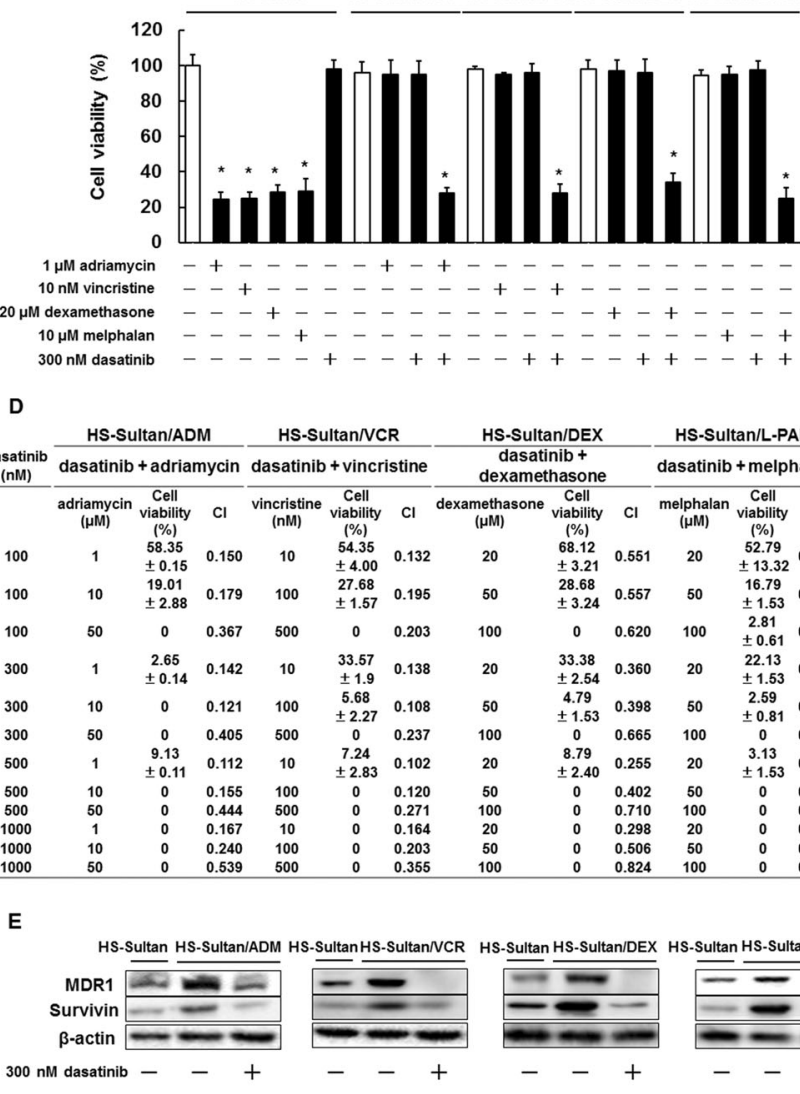
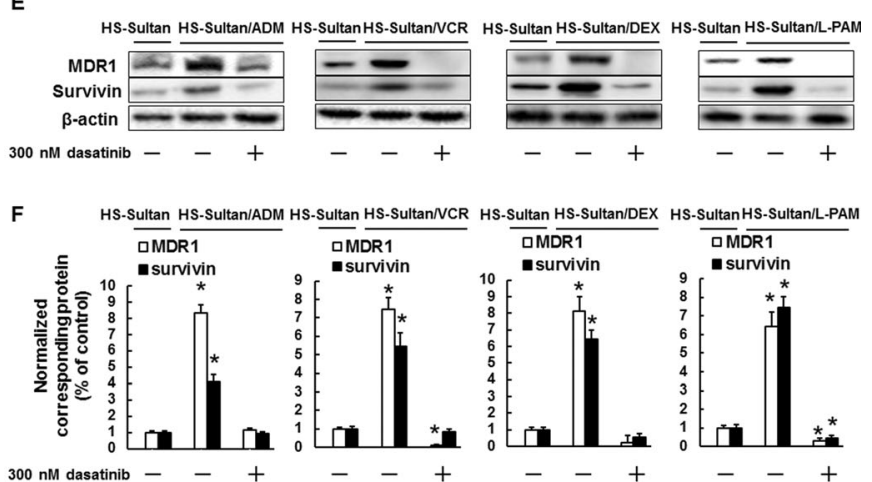
)
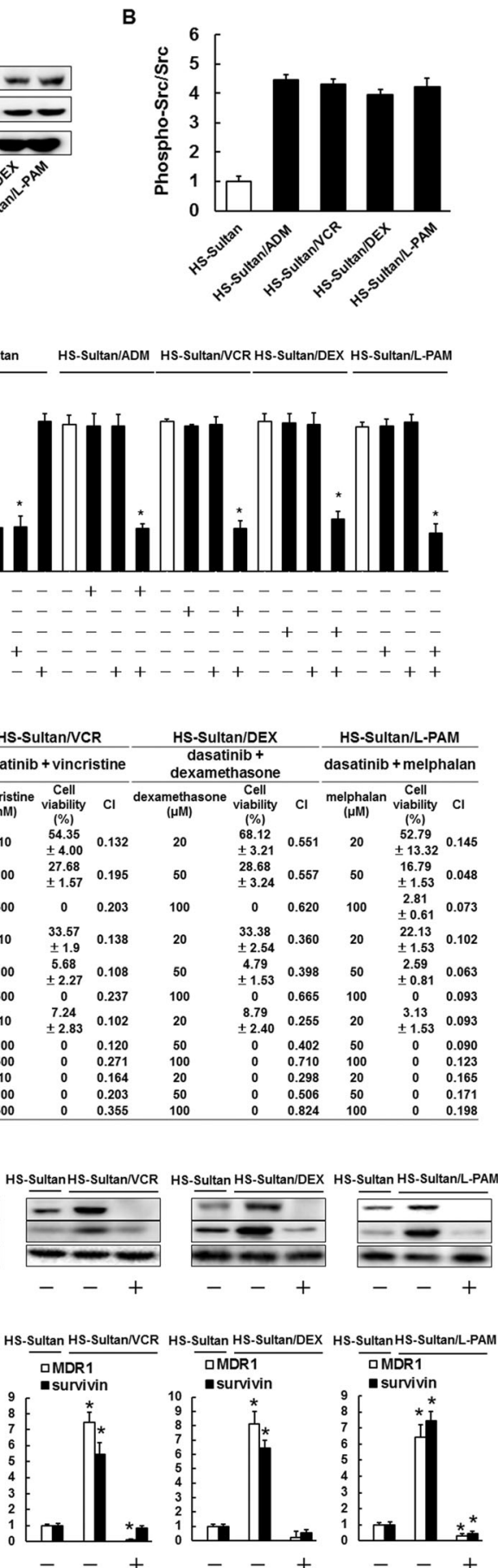

Fig. 4 (See legend on next page.) 
(See figure on previous page.)

Fig. 4 The src inhibitor dasatinib reversed drug resistance in HS-Sultan/ADM, HS-Sultan/NCR, HS-Sultan/DEX, and HS-Sultan/L-PAM cells. a Phosphorylated Src expression levels were assessed by western blotting analysis. Cytoplasmic cell fractions were extracted and performed to SDSPAGE/immunoblotting with anti-Src antibodies. Anti- $\beta$-actin antibodies were used as an internal standard. b Quantification of phosphorylated Src levels. Results were corrected according to total Src levels and are notable example of five independent experiments. ${ }^{*} p<0.01$ vs. control cells (ANOVA with Dunnett's test). c HS-Sultan, HS-Sultan/ADM, HS-Sultan/NCR, HS-Sultan/DEX, and HS-Sultan/L-PAM cells were incubated with the represented concentrations of adriamycin, vincristine, dexamethasone, melphalan, and dasatinib for $72 \mathrm{~h}$. Detection of dead cells number was performed by trypan blue staining. Results are notable example of five independent experiments. ${ }^{*} p<0.01$ vs. control cells (ANOVA with Dunnett's test). $\mathbf{d}$ Combination index (Cl) values for combination treatment of dasatinib and adriamycin, vincristine, dexamethasone, or melphalan were calculated. Cl values less than 1.0 indicate synergy, while $\mathrm{Cl}$ values greater than 1 indicate antagonism. e MDR1 and Survivin expression levels were assessed by western blotting analysis. HS-Sultan, HS-Sultan/ADM, HS-Sultan/NCR, HS-Sultan/DEX, and HS-Sultan/L-PAM cells were incubated with $300 \mathrm{nM}$ dasatinib for $72 \mathrm{~h}$. Cytoplasmic cell fractions were extracted and performed to SDS-PAGE/immunoblotting with anti-MDR1 and anti-Survivin antibodies. Anti- $\beta$-actin antibodies were used as an internal standard. $\mathbf{f}$ Quantification of MDR1 and Survivin levels, normalized to the amount of the $\beta$-actin. Results are notable example of five independent experiments. ${ }^{*} p<0.01 \mathrm{vs}$. control cells (ANOVA with Dunnett's test)

Moreover, dasatinib restores drug sensitivity by reducing MDR1 and Survivin levels in drug-resistant BL cells. Our findings indicate that Src inhibitors could be a novel strategy for treating patients with drug resistant BL.

\section{Supplementary information}

Supplementary information accompanies this paper at https://doi.org/10. 1186/s12906-020-2879-8.

\section{Additional file 1. \\ Additional file 2.}

Additional file 3.

\section{Abbreviations}

BCRP: Breast cancer resistance protein; BL: Burkitt lymphoma; IAP: Inhibitor of apoptosis; IC50: 50\% inhibition concentration; LRP1: Lung resistance protein 1; MDR1: Multiple drug resistance 1; MRP1: Multidrug resistance-associated protein 1; NHL: Non-Hodgkin lymphomas

\section{Acknowledgements}

Not applicable.

\section{Authors' contributions}

MT1 carried out analysis of cell viability, western blotting analysis, PCR analysis, RNAi interface, statistical analysis, and drafted the manuscript. MT2 carried out establishment of drug resistance cell lines, PCR analysis, RNAi interface, and statistical analysis. TT, KT1, and KT2 carried out cell viability assay and western blotting analysis. Ml and TS carried out PCR analysis and statistical analysis. MI, TS, and TI contributed to statistical analyses. SN designed the experiments and revised the manuscript. All authors read and approved the final manuscript.

\section{Funding}

This research did not receive any specific grant from funding agencies in the public, commercial, or not-for-profit sectors.

\section{Availability of data and materials}

The analyzed data sets generated during the study are available from the corresponding author on reasonable request.

\section{Ethics approval and consent to participate}

Not applicable.

\section{Consent for publication}

The authors declare that they agree to submit the article for publication.

\section{Competing interests}

The authors declare that they have no competing interests.

\section{Author details}

'Division of Pharmacotherapy, Kindai University Faculty of Pharmacy, Kowakae, Higashi-Osaka 577-8502, Japan. ²Department of Phamacy, Sakai City Medical Center, Sakai, Japan. ${ }^{3}$ Department of Surgery, Kindai University Faculty of Medicine, Osakasayama, Osaka, Japan. ${ }^{4}$ Department of Pathology, Kindai University Faculty of Medicine, Osakasayama, Osaka, Japan.

Received: 25 September 2019 Accepted: 4 March 2020

Published online: 14 March 2020

\section{References}

1. Ferry JA. Burkitt's lymphoma: clinicopathologic features and differential diagnosis. Oncologist. 2006;11(4):375-83.

2. Thomas DA, Faderl S, O'Brien S, Bueso-Ramos C, Cortes J, Garcia-Manero G, et al. Chemoimmunotherapy with hyper-CVAD plus rituximab for the treatment of adult Burkitt and Burkitt-type lymphoma or acute lymphoblastic leukemia. Cancer. 2006;106(7):1569-80.

3. Ribrag V, Koscielny S, Bosq J, Leguay T, Casasnovas O, Fornecker LM, et al. Rituximab and dose-dense chemotherapy for adults with Burkitt's lymphoma: a randomised, controlled, open-label, phase 3 trial. Lancet. 2016; 387(10036):2402-11.

4. Hoelzer D, Walewski J, Döhner H, Viardot A, Hiddemann W, Spiekermann K, et al. German multicenter study Group for Adult Acute Lymphoblastic Leukemia. Improved outcome of adult Burkitt lymphoma/leukemia with rituximab and chemotherapy: report of a large prospective multicenter trial. Blood. 2014;124(26):3870-9.

5. Intermesoli T, Rambaldi A, Rossi G, Delaini F, Romani C, Pogliani EM, et al. High cure rates in Burkitt lymphoma and leukemia: a northern Italy leukemia group study of the German short intensive rituximabchemotherapy program. Haematologica. 2013;98(11):1718-25.

6. Jacobson C, LaCasce A. How I treat Burkitt lymphoma in adults. Blood. 2014; 124(19):2913-20

7. Short NJ, Kantarjian HM, Ko H, Khoury JD, Ravandi F, Thomas DA, et al. Outcomes of adults with relapsed or refractory Burkitt and high-grade B-cell leukemia/lymphoma. Am J Hematol. 2017;92(6):E114-7.

8. Gottesman MM, Fojo T, Bates SE. Multidrug resistance in cancer: role of ATPdependent transporters. Nat Rev Cancer. 2002;2(1):48-58.

9. Zhang YK, Wang YJ, Gupta P, Chen ZS. Multidrug resistance proteins (MRPS) and Cancer therapy. AAPS J. 2015;17(4):802-12.

10. Mao Q, Unadkat JD. Role of the breast cancer resistance protein (BCRP/ ABCG2) in drug transport--an update. AAPS J. 2015;17(1):65-82.

11. Zhang $Y$, Yang $S H$, Guo XL. New insights into Vinca alkaloids resistance mechanism and circumvention in lung cancer. Biomed Pharmacother. 2017; 96:659-66.

12. Tsubaki M, Satou T, Itoh T, Imano M, Komai M, Nishinobo M, et al. Overexpression of MDR1 and survivin, and decreased Bim expression mediate multidrug-resistance in multiple myeloma cells. Leuk Res. 2012; 36(10):1315-22.

13. Paprocka M, Bielawska-Pohl A, Rossowska J, Krawczenko A, Duś D, Kiełbiński $M$, et al. MRP1 protein expression in leukemic stem cells as a negative prognostic marker in acute myeloid leukemia patients. Eur J Haematol. 2017;99(5):415-22 
14. Muñoz-Pérez MJ, Casco S, Garza-González MDC, Soto-Vega E. P-glycoprotein activity correlates with treatment response in 2 leukemia child patients. J Pediatr Hematol Oncol. 2018;40(8):e490-4.

15. Andreadis C, Gimotty PA, Wahl P, Hammond R, Houldsworth J, Schuster SJ, et al. Members of the glutathione and $A B C$-transporter families are associated with clinical outcome in patients with diffuse large B-cell lymphoma. Blood. 2007;109(8):3409-16.

16. Ohsawa M, Ikura Y, Fukushima H, Shirai N, Sugama Y, Suekane T, et al. Immunohistochemical expression of multidrug resistance proteins as a predictor of poor response to chemotherapy and prognosis in patients with nodal diffuse large B-cell lymphoma. Oncology. 2005;68(4-6):422-31.

17. Lancet JE, Baer MR, Duran GE, List AF, Fielding R, Marcelletti JF, et al. A phase I trial of continuous infusion of the multidrug resistance inhibitor zosuquidar with daunorubicin and cytarabine in acute myeloid leukemia. Leuk Res. 2009;33(8):1055-61.

18. Gerrard G, Payne E, Baker RJ, Jones DT, Potter M, Prentice HG, et al. Clinical effects and P-glycoprotein inhibition in patients with acute myeloid leukemia treated with zosuquidar trihydrochloride, daunorubicin and cytarabine. Haematologica. 2004;89(7):782-90

19. Um HD. Bcl-2 family proteins as regulators of cancer cell invasion and metastasis: a review focusing on mitochondrial respiration and reactive oxygen species. Oncotarget. 2016;7(5):5193-203.

20. Mohamed MS, Bishr MK, Almutairi FM, Ali AG. Inhibitors of apoptosis: clinical implications in cancer. Apoptosis. 2017;22(12):1487-509.

21. Deveraux QL, Reed JC. IAP family proteins--suppressors of apoptosis. Genes Dev. 1999;13(3):239-52.

22. Hassan M, Watari H, AbuAlmaaty A, Ohba Y, Sakuragi N. Apoptosis and molecular targeting therapy in cancer. Biomed Res Int. 2014;2014:150845.

23. Tsubaki M, Takeda T, Tomonari $Y$, Koumoto YI, Imano M, Satou T, et al. Overexpression of HIF-1a contributes to melphalan resistance in multiple myeloma cells by activation of ERK1/2, Akt, and NF-KB. Lab Investig. 2019; 99(1):72-84.

24. Tsubaki M, Takeda T, Tomonari Y, Mashimo K, Koumoto Yl, Hoshida S, et al. The MIP-1a autocrine loop contributes to decreased sensitivity to anticancer drugs. J Cell Physiol. 2018;233(5):4258-71.

25. Tsubaki M, Takeda T, Ogawa N, Sakamoto K, Shimaoka H, Fujita A, et al. Overexpression of survivin via activation of ERK1/2, Akt, and NF-KB plays a central role in vincristine resistance in multiple myeloma cells. Leuk Res. 2015;39(4):445-52

26. Sen B, Johnson FM. Regulation of SRC family kinases in human cancers. J Signal Transduct. 2011;2011:865819.

27. Kim LC, Song L, Haura EB. Src kinases as therapeutic targets for cancer. Nat Rev Clin Oncol. 2009;6(10):587-95.

28. Yang C, Lu P, Lee FY, Chadburn A, Barrientos JC, Leonard JP, et al. Tyrosine kinase inhibition in diffuse large B-cell lymphoma: molecular basis for antitumor activity and drug resistance of dasatinib. Leukemia. 2008;22(9): 1755-66.

29. Ke J, Chelvarajan RL, Sindhava V, Robertson DA, Lekakis L, Jennings CD, et al. Anomalous constitutive Src kinase activity promotes B lymphoma survival and growth. Mol Cancer. 2009;8:132

30. Hollmann CA, Tzankov A, Martínez-Marignac VL, Baker K, Grygorczyk C, Grygorczyk R, et al. Therapeutic implications of Src independent calcium mobilization in diffuse large B-cell lymphoma. Leuk Res. 2010;34(5):585-93.

31. Hatton O, Lambert SL, Krams SM, Martinez OM. Src kinase and Syk activation initiate PI3K signaling by a chimeric latent membrane protein 1 in Epstein-Barr virus (EBV)+ B cell lymphomas. PLoS One. 2012;7(8):e42610.

32. Tsubaki M, Komai M, Itoh T, Imano M, Sakamoto K, Shimaoka H, et al. By inhibiting Src, verapamil and dasatinib overcome multidrug resistance via increased expression of Bim and decreased expressions of MDR1 and survivin in human multidrug-resistant myeloma cells. Leuk Res. 2014;38(1): 121-30.

33. Chen $\mathrm{R}$, Chen $\mathrm{B}$. The role of dasatinib in the management of chronic myeloid leukemia. Drug Des Devel Ther. 2015;9:773-9.

34. Araujo J, Logothetis C. Dasatinib: a potent SRC inhibitor in clinical development for the treatment of solid tumors. Cancer Treat Rev. 2010; 36(6):492-500

35. Wheeler DL, lida M, Kruser TJ, Nechrebecki MM, Dunn EF, Armstrong EA, et al. Epidermal growth factor receptor cooperates with Src family kinases in acquired resistance to cetuximab. Cancer Biol Ther. 2009;8(8):696-703.

36. Ueda $Y$, Igishi T, Hashimoto K, Suyama H, Araki K, Sumikawa T, et al. Synergistic cell growth inhibition by the combination of amrubicin and Akt- suppressing tyrosine kinase inhibitors in small cell lung cancer cells: implication of c-Src and its inhibitor. Int J Oncol. 2009;34(3):689-96.

37. Tsubaki M, Takeda T, Noguchi M, Jinushi M, Seki S, Morii Y, et al. Overactivation of Akt contributes to MEK inhibitor primary and acquired resistance in colorectal cancer cells. Cancers. 2019;11(12):E1866.

38. Tsubaki M, Takeda T, Kino T, Sakai K, Itoh T, Imano M, Nakayama T, Nishio K, Satou T, Nishida S. Contributions of MET activation to BCR-ABL1 tyrosine kinase inhibitor resistance in chronic myeloid leukemia cells. Oncotarget. 2017:8(24):38717-30.

39. Tsubaki M, Komai M, Itoh T, Imano M, Sakamoto K, Shimaoka H, et al. Inhibition of the tumour necrosis factor-alpha autocrine loop enhances the sensitivity of multiple myeloma cells to anticancer drugs. Eur J Cancer. 2013; 49(17):3708-17.

40. Ghetie MA, Marches R, Kufert S, Vitetta ES. An anti-CD19 antibody inhibits the interaction between P-glycoprotein (P-gp) and CD19, causes P-gp to translocate out of lipid rafts, and chemosensitizes a multidrug-resistant (MDR) lymphoma cell line. Blood. 2004;104(1):178-83.

41. Pop IV, Pop LM, Ghetie MA, Vitetta ES. Targeting mammalian target of rapamycin to both downregulate and disable the P-glycoprotein pump in multidrug-resistant B-cell lymphoma cell lines. Leuk Lymphoma. 2009;50(7): 1155-62.

42. Pileri SA, Sabattini E, Falini B, Tazzari PL, Gherlinzoni F, Michieli MG, et al. Immunohistochemical detection of the multidrug transport protein P170 in human normal tissues and malignant lymphomas. Histopathology. 1991; 19(2):131-40.

43. Wang M, Yang W, Li M, Li Y. Low expression of miR-150 in pediatric intestinal Burkitt lymphoma. Exp Mol Pathol. 2014;96(2):261-6.

44. Zyada MM. Relationship of survivin to clinical drug resistance in Burkitt's lymphoma of the head and neck region. Med Oncol. 2011;28(4):1565-9.

45. Kita A, Nakahara T, Yamanaka K, Nakano K, Nakata M, Mori M, et al. Antitumor effects of YM155, a novel survivin suppressant, against human aggressive non-Hodgkin lymphoma. Leuk Res. 2011;35(6):787-92.

46. Tabata M, Tsubaki M, Takeda T, Tateishi K, Maekawa S, Tsurushima K, et al. Inhibition of HSP90 overcomes melphalan resistance through downregulation of Src in multiple myeloma cells. Clin Exp Med. 2020;20(1): 63-71.

47. Mashimo K, Tsubaki M, Takeda T, Asano R, Jinushi M, Imano M, et al. RANKLinduced c-Src activation contributes to conventional anti-cancer drug resistance and dasatinib overcomes this resistance in RANK-expressing multiple myeloma cells. Clin Exp Med. 2019;19(1):133-41.

48. Lin YP, Wu Jl, Tseng CW, Chen HJ, Wang LH. Gjb4 serves as a novel biomarker for lung cancer and promotes metastasis and chemoresistance via Src activation. Oncogene. 2019;38(6):822-37.

49. Rao G, Kim IK, Conforti F, Liu J, Zhang YW, Giaccone G. Dasatinib sensitises KRAS-mutant cancer cells to mitogen-activated protein kinase kinase inhibitor via inhibition of TAZ activity. Eur J Cancer. 2018;99:37-48.

50. Huang XP, Li X, Situ MY, Huang LY, Wang JY, He TC, et al. Entinostat reverses cisplatin resistance in esophageal squamous cell carcinoma via down-regulation of multidrug resistance gene 1. Cancer Lett. 2018;414:294300.

51. Chen T, Wang C, Liu Q, Meng Q, Sun H, Huo X, et al. Dasatinib reverses the multidrug resistance of breast cancer MCF-7 cells to doxorubicin by downregulating P-gp expression via inhibiting the activation of ERK signaling pathway. Cancer Biol Ther. 2015;16(1):106-14.

\section{Publisher's Note}

Springer Nature remains neutral with regard to jurisdictional claims in published maps and institutional affiliations. 